\title{
Performance, Power and Condom Use: Reconceptualised Masculinities amongst Western Male Sex Tourists to Thailand.
}

\begin{abstract}
Each year large numbers of Western men travel to Thailand as sex tourists. Although many will use condoms during their sexual encounters, others will not, potentially exposing themselves to the risk of acquiring sexually transmitted infections, including HIV. Although sex tourism in Thailand has been well documented, the social drivers underpinning voluntary sexual risktaking through the avoidance of condoms remain poorly understood. Engaging with R. W. Connell's concept of hegemonic masculinity, and drawing on data collected from 1237 online discussion board posts and 14 face-to-face interviews, this study considers the ways in which understandings and performances of masculinities may inform the sexual risk-taking behaviours of Western male sex tourists. It argues that for some of these men, unprotected sex is not viewed as a reckless behaviour but instead as a safe and appropriate masculine practice, supported by relationships that are often framed as romantic and within a setting where HIV is still largely considered a homosexual disease. With sex workers often disempowered to demand safer sexual practices, and men's attitudes towards unprotected sex deeply entrenched and resistant to external health promotion advice, the paper concludes by considering what this means for policy and practice.
\end{abstract}

\section{Keywords}

Bareback, Male sexuality, Masculinity, Sex tourism, Thailand 


\section{Introduction}

Much has been written about the men who participate in sex tourism in Thailand, and on the women whom they pay for sex (Ryan and Hall 2001; Hobbs et al. 2011; Syvertsen et al. 2015; Lim and Cheah 2016). However, most of this has focused on the behaviour of individuals (Garrick 2005; Manieri et al. 2013), leaving the homosocial spaces and peer networks that male sex tourists (MSTs) engage with poorly explored. This article considers two such spaces, one virtual and the other physical. In doing so, it identifies locally hegemonic masculine groups, perpetual and yet populated by transients, and reflects on their potential influence on their members attitudes towards women, sex and risk.

While Thailand is a popular tourist destination, the country also has the reputation of being one of the most important locations in the world for sex tourism, particularly for European and Asian men (Lyttleton 2000; Yokota 2006; Singh and Hart 2007). Although prostitution is technically illegal in Thailand (Khruakham and Lawton 2012), paid-for sex remains available to men in a variety of different settings, both formal and informal. Sexually transmitted infections (STIs) pose a significant threat to both Thai female sex workers (FSWs) and the men who purchase sex from them, with HIV being of particular concern (Nhurod et al. 2010; Manopaiboon et al. 2013). While condoms are an effective way to protect against the transmission of most STIs, including HIV, many men who engage in paid-for sexual activity while overseas still choose not to use them (Herold and Van Kerkwijk 1992; Bloor et al. 1998; Manieri et al. 2013). Although this decision may often be spontaneous, in response to changing social boundaries as tourists move into new geographical spaces or else to the increased level of alcohol consumption that typically accompanies this (Downing et al. 2011; Hesse and Tutenges 2011), there is also evidence that men's participation in unprotected sex with FSWs is sometimes a planned decision. Manieri et al. (2013) found that amongst a group of Swedish MSTs interviewed in Thailand, 20\% reported planning to engage in sex with FSWs without the 
use of a condom. This is not just a Swedish problem. Through their analysis of the UK national HIV database, Rice et al. (2012) identified that roughly 15\% of new HIV diagnoses in UK-born persons between 2002 and 2010 were acquired outside the UK, with the highest prevalence found amongst men who had been infected in Thailand.

Although both sexual intercourse and condom use are, theoretically, negotiated behaviours, power is often unequally distributed between negotiating partners and there exists the potential for pressure and coercion from men to demand unprotected sex (Jewkes et al. 2010; Fair and Vanyur 2011; Swan and O'Connell 2011). This type of systematic inequality in power between genders underpins Connell's (1987) theory of hegemonic masculinity, in which masculinities are viewed as configurations of practice, structurally embedded within society and operating to ensure the dominance of men and the subordination of women. However, although hegemonic masculinity might help to explain how men are able to exercise gendered power in order to coerce women into engaging in unprotected sex, it largely ignores the reasons why they would want to if it also places them at risk. Explanations given for men's desire not to use condoms include that it is more physically pleasurable (Mizuno et al. 2007; Brown et al. 2008), or that some may enjoy the psychological thrill that they associate with the risks of unprotected sex (Ridge 2004). However, while either of these may be sufficient explanation in some circumstances, the particularly high risks associated with engaging in unprotected sex with sex workers are well known (Manopaiboon et al. 2013). Manieri et al. (2013) highlight that most of the men in their study who planned to engage in unprotected sex with FSWs were in their forties or older. They argue that, because of their age, these men should have been aware of the risks that they were taking, having been exposed to major 'safe sex' campaigns during the 1990's. Such apparent recklessness, particularly amongst this group of potentially wellinformed men, creates a paradox that is difficult to resolve. 
One clue to unravelling this problem may have something to do with the very thing that should arguably have made these men less inclined to take such sexual risks, their age (Wright 2003). Hegemonic masculinity in the West, while privileging all men over women, tends to favour some masculinities over others, particularly those of young, white, affluent, aggressive and (hetero)sexually successful men (Arxer 2011; Foweraker and Cutcher 2012). While those who configure their performances of gender most closely in accordance with the hegemonic ideal stand to gain the greatest social benefit, some men will always remain on the fringes. This paper seeks to explore the gap in knowledge around masculinities as socialised configurations of practice and the ways in which these potentially inform the sexual risk behaviour of Western MSTs to Thailand. In doing so it presents a way of understanding the behaviour of these men, particularly older and less affluent men, as participants within a locally reconceptualised hegemony crafted in their image, a homosocial space in which unprotected sex with FSWs is a normalised and approved behaviour.

\section{Method}

The study draws on data from two distinct sources, online discussion board posts and face-toface interviews with MSTs in Thailand. Online discussion boards were identified through an English language keyword search of the internet using the three most commonly used search engines, Google, Yahoo and Bing (Experian Hitwise 2014). In order to be included, discussion boards had to be in English, be publically available and not password protected, be written ostensibly by and for heterosexual Western MSTs of any nationality, and date from no earlier than 2009. Consent was not sought from the authors of online posts as these were drawn solely from public discussion boards. This is in line with Anderson and Kanuka's (2003) argument that the expectation of privacy, rather than ownership, should dominate the discourse around 
the ethics of using online data, and individuals who post comments on open public discussion boards can realistically only have a relatively low expectation of privacy (Williams et al. 2008).

The names of all post authors, although invariably pseudonyms, were changed at the point of data collection to help preserve anonymity (Markham and Buchanan 2012). However in order to present the findings of this study as authentically as possible, the decision was made not to paraphrase content drawn from discussion board posts but rather to present the data verbatim. One problem with this approach is that it might be possible for a third party to search for these quotes online, find the original posts and usernames, and so undermine any attempts made to anonymise (Dawson 2014). In order to mitigate this concern an internet text search was conducted using Google for each discussion board post included in the results section of this paper, and no authors were identifiable by these means. Overall, this arm of the study identified 1237 individual discussion board posts, containing approximately 190,000 words in total. Posters were not required to provide any personal information on the discussion boards, however those who did were predominantly over 40 years of age and resident in the UK, the US or Australia. All data collected during this process were securely stored on a single encrypted data drive.

The second stage of the data collection process utilised fourteen in-depth, semi-structured interviews conducted with MSTs in Pattaya, Thailand during a three-week period between May and June 2014. Pattaya was chosen as the site for this arm of the study because it is one of the key centres for Western sex tourism in Thailand (Garrick 2005; Manieri et al. 2013). Although arguably not representative of all Western MST venues in Thailand, it was the most commonly cited venue by discussion board posters and so loosely connected the two data sources. Participants were recruited purposively by approaching Western men in open public spaces during the day, explaining the nature and purpose of the research and then asking for their participation. Although the study was impacted to some degree by a military coup halfway 
through the data collection period, we were able to recruit a total of fourteen men aged between 37 and 71, with a mean age of 54. Each participant was given an information sheet and a consent form, which they were asked to read and then sign. Interviews were conducted in quiet public venues, predominantly within street cafes. They followed an in-depth, semi-structured format, lasted approximately forty-five minutes each and were audio recorded. The interview schedule drew heavily from Connell's (1987) theory of hegemonic masculinity, beginning with rapport building questions before moving on to explore how the participants understood and performed masculinities, and their wider beliefs about gendered power and the role of women. Finally, participants were asked about their views on sexual risk, specifically with regard to paid-for sex and condom use. All participants were anonymised at the point of data collection and interviews were transcribed by the lead author before being stored on an encrypted data drive.

Discussion board and interview data were initially analysed separately using thematic analysis (Braun and Clarke 2006), which involved reading the discussion board posts and interview transcripts several times followed by manual coding and the development of preliminary themes. The coding process was conducted through the a priori lens of Connell's hegemonic masculinity, with specific attention being given to gendered configurations of practice, perceptions of power and attitudes towards sexual risk. However, the analysis strove to be as reflexive as possible in its interaction with the data so that unexpected themes might also be permitted to emerge. Because the interview process had been disrupted by a coup, limiting the number of participants to fourteen, we wanted to obtain some sense of how saturated the interview data were (Mason 2010; Bonde 2013). On analysis, it became evident that all of the themes to arise within the interview data did so during the first eight interviews. This provided us with some confidence that the views of this group of men in Pattaya had been meaningfully captured within the sample. 
Once preliminary themes had been identified within the two data sets they were brought together in order to explore areas of agreement and difference, and to provide a more detailed and balanced understanding of the findings (Altrichter et al. 2007, 147). This process of triangulation facilitated the development of a final set of overarching themes that reflected the dominant narratives within the data, but also highlighted differences between the two sources where they occurred.

\section{Results}

Three overarching, but interwoven themes were identified from the data: the construction of masculinities, the authentication of these constructions and perceptions of sexual risk. Embedded within these themes were four types of gendered performance; approved masculinities (heterosexual male sex tourist practices), subordinate masculinities (the practices of homosexual men and non-sex tourists), approved femininities (Thai women) and subordinate femininities (Western women). Although a greater volume of data were collected from discussion boards, interview data was a far richer source of information. Discussion board posters engaged primarily with the mechanics of sex tourism - where to meet sex workers, how much to pay them and how to avoid contracting an STI - with men sharing very little of themselves. In contrast to this, the men interviewed in Thailand shared far more about their own histories and their attitudes towards women, each other and the outside world.

\section{Masculinities constructed}

All of the participants within this study ostensibly travelled to Thailand in order to engage in paid-for sexual activity with Thai women, however for the men interviewed in Pattaya, the setting held much more for them than sexual gratification alone. For this group Pattaya represented a masculinity-affirming social space that provided substantial opportunities for 
like-minded Western men to interact with each other and build friendships. Bars and restaurants were filled all day long, and late into the night, with Western men in conversation:

Always, you can easily make friends here because you're here, you're all here for the same reason, you're all here to have a good time...

Roger, 61 year old electrician (Interview)

These men were bound together, not only through the shared practice of sex tourism but also to some extent by language; going 'bareback' for having unprotected sex and adopting the Thai word for foreigner, 'Falang' or 'Farang', as a way of referring to themselves and each other. While such friendships with men in Pattaya were valued, they were juxtaposed to a wider resentment of other Western men back home, non-sex tourists who many felt sought to subordinate them for their participation in sex tourism:

I came for holidays originally and when I went back to the UK, 'Oh here comes the paedophile.' I was labelled in my local pub, paedophile. 'You go Thailand, don't you? Well we know all about Thailand'

George, 71 year old retired (Interview)

However, rather than accepting this view of their behaviour as subordinate, several responded by counter-labelling their male critics as men in denial of their own desires, dominated by their wives and too fearful to become sex tourists themselves. Relative to this group, the men in this study largely constructed themselves, not as 'lesser' men as they might be seen by others, but rather as smarter, braver and more honest, as more masculine men, than those who chose not to engage in sex tourism: 
I say, 'Look, don't take the mick out of me. You don't know, you've never been so don't knock me'... They're all jealous, they all want to come.

\section{Mark, 47 year old factory worker (Interview)}

Several of the older men also raised the issue of their advancing years as an emasculating and disempowering factor for them in the West. However, the view was that in Thailand older men were valued more than younger men, and that youth and physical attractiveness granted no advantage:

The young guys, the young guys, they don't last long, and the reason for that is, they're all shirts off, they've got good bodies, and they come here, and they get a beautiful, beautiful Thai girl, and take them back to room... The next day a 60 year old has got the same woman, and he thinks, 'What's this all about?'. They don't come back, because they, they don't like that... basically it's an old persons place. They want 40-up, a Thai girl in Pattaya wants 40-up.

Brian, 59 year old unemployed (Interview)

For those interviewed, the things that they felt subordinated them in the West, their age, their attractiveness and, by Western standards, their typically modest financial means were nonissues in Pattaya. They formed the majority here and so were able to collectively construct and perform their masculinities both in relation to each other as well as in opposition to 'lesser' groups of men, the non-sex tourist and the ignorant youth. In this way, they helped to construct and maintain a locally reconceptualised aggregate of approved masculinities where being an older male sex tourist granted you acceptance by a hegemony that held substantial social and 
economic power. Offering position, inclusion and status to so many who felt disempowered back home, Thailand was a place to be a man again.

\section{Masculinities authenticated}

Across the data, what ultimately bound all the men in this study together was their collective status as MSTs. Although the men were able to construct and, to some extent perform, locally approved masculinities through their social interactions with each other, they ultimately required engagement with women in order to fully authenticate these performances. When discussing Western women, most of the men interviewed presented a beleaguered masculinity, expressing feelings of disempowerment or rejection by women at home who had taken their houses, divorced them and did not want them anymore:

I'd had two failed marriages, bought two houses, my ex's kept them. Basically I bought the house, they kept them... on the sale of the second house I had about 15 thousand pound and a lot of time and holiday that I had to take, and I thought, do you know what? I'm going to try Thailand for a week.

Mark, 47 year old factory worker (Interview)

This construction of Western women as negative, even toxic, was used to provide justification - the 'push' - for several of the men's participation in sex tourism. In contrast to women from the West, Thai women (which almost always referred to sex workers) were appointed with a very different set of physical and behavioural characteristics that were highly valued by men - the 'pull' of Thailand. They were viewed as being more desirable, not explicitly because of their ethnicity but because they were young, attractive and affectionate: 
You come here from England and the cold and you've got beautiful little things loving you to bits.

Stan, 70 year old retired (Interview)

Women in Thailand were also considered to possess more traditional (which was generally a euphemism for subordinate) values than Western women, values that worked to permit and authenticate the performance of a dominant masculinity by MSTs. By paying their money these men received more than sex, they obtained, albeit for a limited time, the attention of a young, attractive woman who would be subservient to the majority of their desires, both carnal and domestic - they would bathe them, clean up after them and run errands:

Say I run out of fags? I can wake her up, 4 o'clock in the morning, and say, 'Go get me some fags', she'll get dressed and go out and get some. An English woman, she'd turn over and go back to sleep. They do, they look after you.

Roger, 61 year old electrician (Interview)

Collectively these performances, subordinate and commodified, appeared to work to blur the line between the commercial and the romantic, with all of the men interviewed reporting being in, or having been in, a romantic relationship with a Thai FSW. There was a very clear change of language when men spoke about these romantic relationships. Where they might talk of paying for sex with a 'sex worker' or a 'hooker', the women with whom they considered they had a romantic relationship were instead relabelled as a 'girlfriend'. Without exception, all of the men who reported having had a Thai girlfriend in Pattaya had met them as a consequence of a previous commercial sexual encounter: 
... you stay with a girl for a week, and you think that's your girlfriend, even if you meet them in a bar.

Steve, 45 year old businessman (Interview)

However, following their relabelling there was nothing obvious to differentiate girlfriends who were sex workers from any other type of romantic relationship. Men often recounted how they had met their girlfriend and how long they had been together, occasionally sharing photographs of them from their wallet. Yet, despite the objective fantasy of romantic love, the relabelled Thai girlfriend was a locally approved norm. It was not just about sex either, as men would freely admit to seeking that from other sex workers at the same time. Obtaining a girlfriend offered something else, something more, it provided confirmation of romantic success, which carried value even in a setting where there was no need to have a romantic relationship in order to have a sexual one. Even though having a girlfriend who was also a sex worker meant that payment would be required in order to maintain the relationship, there was no real conflict seen between performances of romantic love and financial reward; rationalisations were made and the hegemony adapted:

You pay for your wife back home, if you have a wife back home. She has her pocket money or allowance... Same here, you know what I mean?

Michael, 68 year old retired (Interview)

For the men in this study, their participation in paid-for sexual encounters with FSWs did not undermine their masculinities as it might do in the West, rather it validated them. Back home they were just ordinary men, somewhat at odds with the Western hegemonic ideal, middle-aged, frequently divorced and alone. In Pattaya, however, they were transformed, their 
status elevated by a hegemony that they both participated in and helped to construct. In their eyes, they had got it right and there was nothing ironic about the way that they saw themselves or their practice; they had left behind somewhere that they felt unvalued and disempowered, and found a setting that both privileged and authenticated them as men.

\section{Condoms, risk and sexual relabelling}

Only when discussing condom use did discussion board posters step beyond just sharing practical information and begin to use more emotive language. Posters were broadly divided into two groups, those that argued that condoms should be used with FSWs and those that viewed condoms as unnecessary. Men in favour of using condoms asserted that it was the responsible thing to do and framed themselves as rational, sensible and caring men, labelling anyone who suggested participating in unprotected sex as stupid, selfish or reckless:

There is a chance your actions may eventually kill someone, or multiple people. People are put into prison or called mentally ill with this type of thinking.

\section{Likeher (Discussion board poster)}

On the other side of the debate were men who reported, and occasionally advocated, practicing unprotected sex with FSWs in Thailand. These men's masculinities were performed as tough, virile and fearless - as much more traditionally hegemonic (Connell 1987; Connell 2005) - and they responded to their critics by counter-labelling them as weak and fearful, as essentially unmanly, of wanting to engage in unprotected sex but lacking the courage. In this way, it mirrored the rebuttals levelled by the men interviewed in Pattaya against the non-sex tourist males who criticised them: 
For those who are really worried about STDs, you can always buy XXX DvD's at Pantip or Sukhumvit, Vaseline @ 7/11 store then go back to your room and jack off (masturbate). FreddyF (Discussion board poster)

This tension between two competing masculine typologies stacked the argument in favour of unprotected sex. While non-condom users might be labelled as bad people, their masculinities were never challenged, whereas men arguing in favour of condoms found their 'manliness' immediately brought into question; condom use equated to fear and fear was not a masculine emotion. In this way, the online community systematically favoured the 'bad' men over the 'good' in terms of their performance of an approved masculinity - it was far easier for 'bad' sex tourists to be considered 'real' men than it was for 'good' sex tourists. Certainly, this narrative had a strong appeal for many posters, not only those who practiced unprotected sex themselves and so could have their behaviour validated by the comments of others, but also amongst men who did not practice unprotected sex but aspired to:

He who has the balls to bareback it with a ho (sex worker), gets my respect! I just don't have the balls yet, but I am tempted to every time.

Brit_Jon (Discussion board poster)

Of the men interviewed in Pattaya, none reported using condoms consistently in their sexual interactions with FSWs. While men would commonly state that they used condoms with sex workers in brothels and massage parlours, most confirmed that they did not use condoms with women who they considered to be their girlfriends, regardless of the circumstances in which they first met. While there was agreement that unprotected sex felt more pleasurable, the practice was also tightly linked to the overall authenticity of the experience of romantic success, 
as if to use a condom would reveal the relationship to be the commercial entity that it was. Using condoms with a regular girlfriend was not only viewed as undesirable, it was also largely considered unnecessary:

If you're playing around with various women, wear a condom. If you have one woman, right, you don't need that.

Derek, 58 year old retired (Interview)

This attitude to condom use within romantic relationships also sat within a wider understanding of unprotected sex as a generally low-risk activity. Because most STIs were felt to be easily treatable, it was only HIV that raised any real concern amongst either the interviewees or the discussion board posters. However, the general view was that HIV was primarily a homosexual disease and unlikely to be a significant risk to heterosexual men, although for some discussion board posters any risk was too much risk. This idea was prevalent to such an extent that where an apparently heterosexual man was known to have acquired HIV, transmission was blamed on hidden homosexual practices:

I know a guy here, from Sheffield... he's HIV positive. It was his girlfriend, she's HIV positive as well, had give it to him... but I thought it wasn't as easy to catch like that. I said to Gary, I said, 'Has he ever been with blokes or lady boys or owt like that', he said, 'Didn't you know?', 'No', I said, 'I didn't', 'Oh yeah, he swings both ways'... he's gone back to England now, getting treatment in England.

Mark, 47 year old factory worker (Interview) 
Although men were aware of external health promotion advice around the heterosexual transmission of HIV and the need to use condoms, the ability of governments and mainstream media to provide reliable information was widely distrusted. As with their rejection of Western women and their Western male critics, some of the participants also rejected Western sexual health advice outright, considering it less concerned with protecting their health but rather about trying to disempower and control them:

Never believe what you hear on TV, it's all bullshit. I don't watch TV anymore, I get all my information from the internet about everything because the mainstream media will tell you lies like you can't believe. I never listen to them.

Bob, 56 year old publican (Interview)

Overall, there was much to encourage men to engage in unprotected sex with FSWs, and little to dissuade them; it was seen as masculine, authentic, pleasurable and broadly safe. There were dissenting voices but the impact of these was generally muted because they were either associated with fear, an unmanly emotion, or else a product of the distrusted 'safe sex' discourse of the West.

\section{Discussion}

Participants in this study were drawn from two different spaces, one virtual and the other physical. Discussion boards provided an anonymous and safe space in which localised social norms, including the acceptability of paying for sex, were able to prosper even if these were far removed from wider societal norms (Kendall 2000; Manago 2013). Sexual risk was a popular but contested topic here, however the problem facing men who argued in favour of using condoms was that, whatever was said about safer sex being the smart and responsible thing to 
do, there was always some association between condom use and fear; one used a condom because one was frightened about contracting an STI. Fear is not an approved masculine performance, in fact quite the opposite (Treffke et al. 1992; Plummer 2013; Fladseth et al. 2015). MSTs might debate condoms online, but ultimately it remained difficult for any man to advocate their use and still assert that they were as masculine as those who reported that they did not. Although these data provided little in the way of detailed explanations around risktaking behaviours, their overarching narrative added significantly to the draw of unprotected sex; not only did it feel better but engaging in it made one more of a man.

The second space for MSTs to reconceptualise hegemonic masculinity was within the physical place of practice, which for the men in this study was Pattaya. Bonded by their liminal homosociality, both as MSTs and foreigners (Arxer 2011; Brown et al. 2012), none of the men interviewed would have carried a high masculine status in the West (Connell 2005). As a group, they were middle-aged or older, and not wealthy by Western standards being typically working class or else retired, and yet in Pattaya their status as men was transformed. There no one judged them, all the girls loved them and every man was their friend, but it was all just theatre, a stage upon which masculinities could be constructed, performed and validated. Unlike the online discussion boards, masculinities in Pattaya were also overtly constructed in relation to women who, while still viewed essentially as commodities, provided performances of their own. Connell and Messerschmidt (2005) acknowledge the role of the agency of women in the construction and maintenance of the hegemony despite their ultimate subordination by it, and FSWs in Pattaya performed their gender in ways that the men approved of and found desirable. Although notions of race may also have played a part in underpinning men's behaviours (Williams 2013), these did not form an explicit part of their narratives, rather what seemed to matter most were the performances of highly sexualised, submissive femininities (Sanders 2005). Such performances worked to blur the line between the commercial and the romantic, 
and men frequently relabelled FSWs as girlfriends, even after a relatively short time. These relationships mirrored the sexual scripts of conventional romantic relationships (Sanders 2008), providing what Bernstein (2007) refers to as 'bounded authenticity', the feeling of an emotional connection that was valued despite its illusory nature (Huysamen and Boonzaier 2015). Where they felt that Western women had first dominated them and then rejected them, the performances of Thai FSWs made them feel both wanted and authentic as men (Kong 2015). Such relationships were openly worn, and sometimes flaunted, and the fact that women's performances were widely understood not to be genuine mattered far less than the effect that they had on buttressing men's self-esteem (Parreñas 2006).

However, perhaps the most significant consequence of this relabelling of sex workers to girlfriends was that it immediately led to a sense of sexual de-risking and substantially less condom use; it was not considered necessary, nor authentic, to use a condom with a girlfriend, even if that girlfriend had been a sex worker just a few days earlier. This behaviour was further supported by a general view, particularly in Pattaya but also to some degree within the discussion boards, that unprotected heterosexual sex was essentially a low risk practice; most STI's represented merely a transient inconvenience and HIV was broadly considered to be a homosexual disease. It was not that men were naïve to the external health information and advice that warned them about the risks of unprotected sex, it was that these messages did not tally with their own experiences nor with those of their peers; in this setting the internal knowledge of the hegemony held primacy. Like the critics of sex tourism they had known back home, and who they actively sought to subordinate as fearful, lesser men, governments and other agencies were viewed as seeking to control their behaviour and stop them from doing what they wanted to. Consequently, information that came to them via mainstream media, whether it was part of a health promotion campaign or simply a news story, was also subordinated, distrusted as having ulterior motives. Because of this many MSTs, both online 
and in Pattaya, chose to isolate themselves from much of the evidence-base that directly affected their own sexual health; they felt that the West had rejected them for who they were and so they rejected it right back.

Although this study provides some insight into the role of a reconceptualised form of hegemonic masculinity on the sexual risk-taking behaviours of Western MSTs to Thailand, there are a number of limitations. When providing data, discussion board posters were engaging with each other as peers and they could opt in or out of discussions as they wished. Conversely, the men interviewed in Thailand were aware that they were participating in a research study, and although they were free to withdraw at any time, to do so would have been socially awkward and so none did. Because of these differences, it would be unrealistic to argue that these two sets of data are directly comparable. Even the data collected from Pattaya cannot necessarily be considered representative of Western MSTs elsewhere in Thailand, where the transient tourist in Bangkok may harbour very different motivations to the retired electrician who may be resident in Pattaya for a month or more. It is also important to acknowledge that all of the data within this study, both online and from interviews, represents only a performance as men shared what they wished to share and presented themselves in ways in which they wanted to be perceived. However, each provides a window into the social world of these men as sex tourists, small and somewhat opaque, and yet still potentially important to understanding their motivations for taking serious sexual risks.

\section{Conclusions}

Not all men match the Western hegemonic ideal, are young, handsome, wealthy and powerful, in fact many men are none of these things. Trapped within what Faludi (1999) refers to as a 'crisis of masculinity', unprotected sex served as a mark of being a 'real' man authenticating both romantic and broader masculine success. These findings provide further 
evidence that hegemonic masculinity can operate in a flexible and locally reconfigurable manner across both physical and virtual spaces, so long as it continues to privilege men over women (Connell and Messerschmidt 2005). In this way, groups of men who may differ from the Western hegemonic ideal may still validate their masculinities as approved within a reconceptualised hegemony, so long as a space exists for them to do this.

The embedding of unprotected sex within the performance of approved masculinities suggests that standard health promotion approaches may struggle to achieve behaviour change in these men. Perhaps as a reflection of this, almost all sexual health promotion efforts in Thailand are currently focused towards empowering FSWs to protect themselves (Treerutkuarkul 2010; Wariki et al. 2012). One problem with this approach is that there remains a substantial economic pressure on sex workers in Thailand to offer what men demand of them. In a conversation held outside the formal data collection process, one of the men interviewed explained that he could always find what he wanted in Pattaya; if one girl refused, there were always others who would agree, either for more money or simply to obtain a customer. With this in mind it seems an impossible task to sufficiently empower this group of economically disadvantaged Thai women to insist on condoms against the backdrop of a powerful local hegemony that insists more loudly, although often implicitly, that they should not. One answer may lie in thinking more about the ways in which MSTs gather and value risk knowledge, and how they incorporate this into their own sexual risk-taking decisions. While the men in this study were often highly suspicious of external health promotion messages, they valued their own experiences and the opinions of their peers, views that largely supported unprotected sex with Thai FSWs as acceptable and safe. Ultimately, only intervention by the Thai government to reduce the widespread availability and acceptability of prostitution to Western MSTs may be enough. Unfortunately, as long as sex tourism continues to bring vast amounts of foreign currency into the country, the motivation for change will likely remain insufficient. 


\section{References}

Altrichter, Herbert, Allan Feldman, Peter Posch, and Bridget Somekh. 2007. Teachers investigate their work: An introduction to action research across the professions. 2 nd ed. Abingdon: Routledge.

Anderson, Terry and Heather Kanuka. (2003). E-Research: Methods, strategies and issues. Boston: Pearson.

Arxer, Steven L. 2011. "Hybrid Masculine Power: Reconceptualizing the Relationship between Homosociality and Hegemonic Masculinity." Humanity \& Society 35(4): 390-422. doi:10.1177/016059761103500404.

Bernstein, Elizabeth. 2007. Temporarily yours: Intimacy, authenticity, and the commerce of sex. Chicago: University of Chicago Press.

Bloor, Michael, Michelle Thomas, Kerenza Hood, Damiano Abeni, Catherine Goujon, Dominique Hausser, Michel Hubert, Dieter Kleiber, and Jose Antonio Nieto. 1998. "Differences in sexual risk behaviour between young men and women travelling abroad from the UK." Lancet 352(9141): 1664-1668. doi:10.1016/S0140-6736(98)09414-8.

Bonde, Donna. 2013. "Qualitative Interviews: When Enough is Enough.” Accessed May 2 2017. http://researchbydesign.com.au/downloads/qualitative-market-research-enoughenough.

Braun, Virginia, and Victoria Clarke. 2006. "Using thematic analysis in psychology." Qualitative Research in Psychology. 3(2): 77-101. doi:10.1191/1478088706qp063oa.

Brown, Larry. K., Ralph Diclemente, Richard Crosby, M. Isabel Fernandez, David Pugatch, Sylvia Cohn, Celia Lescano, Scott Royal, Jacqueline R. Murphy, Barbara Silver, and William E. Schlenger. 2008. "Condom Use Among High-Risk Adolescents: Anticipation of Partner Disapproval and Less Pleasure Associated with Not Using Condoms." Public Health Reports 123(5): 601-607. doi:10.1177/003335490812300510. 
Brown, Graham, Jeanne Ellard, Julie Mooney-Somers, Janina Hildebrand, and Trish Langdon. 2012. "HIV risk among Australian men travelling overseas: networks and context matter." Culture, Health \& Sexuality 14(6): 677-690. doi:10.1080/1369105.

Connell, R. W. 1987. Gender and Power: Society, the Person and Sexual Politics. Cambridge: Polity Press.

Connell, R. W. 2005. Masculinities. 2nd ed. Cambridge: Polity Press.

Connell, R. W, and James W. Messerschmidt. 2005. "Hegemonic Masculinity: Rethinking the concept.” Gender \& Society 19(6): 829-859. doi:10.1177/0891243205278639.

Dawson, Phillip. 2014. "Our anonymous online research participants are not always anonymous: Is this a problem?” British Journal of Educational Technology 45(3): 428-437. doi:10.1111/bjet.12144.

Downing, Jennifer, Karen Hughes, Mark A. Bellis, Amador Calafat, Montse Juan, and Nicole Blay. 2011. "Factors associated with risky sexual behaviour: a comparison of British, Spanish and German holidaymakers to the Balearics." The European Journal of Public Health 21(3): 275-281. doi:10.1093/eurpub/ckq021.

Experian Hitwise. 2014. "Consumer Search Engine Trends." Accessed January 272014. http://www.experian.com/marketing-services/online-trends-search-engine.html.

Faludi, Susan. 1999. Stiffed: The Betrayal of the Modern Man. London: Harper Collins.

Fair, Cynthia. D., and Jennifer Vanyur. 2011. "Sexual coercion, verbal aggression, and condom use consistency among college students.” Journal of American College Health 59(4): 273280. doi:10.1080/07448481.2010.508085.

Fladseth, Kristin, Mitzy Gafos, Mary Louise Newell, and Nuala Mcgrath. 2015. "The Impact of Gender Norms on Condom Use among HIV-Positive Adults in KwaZulu-Natal, South Africa.” PloS one 10(6): 1-19. doi:10.1371/journal.pone.0122671. 
Foweraker, Barbara and Leanne Cutcher. 2012. "Work, Age and Other Drugs: Exploring the Intersection of Age and Masculinity in a Pharmaceutical Organization.” Gender, Work \& Organization 22(5): 459-473. doi:10.1111/gwao.12085.

Garrick, Damien. 2005. "Excuses, Excuses: Rationalisations of Western Sex Tourists in Thailand." Current Issues in Tourism 8(6): 497-509. doi:10.1080/13683500508668233.

Herold, E. S. and C. Van Kerkwijk. 1992. "AIDS and sex tourism.” AIDS and Society 4(1): 18.

Hesse, Morten, and Sébastien Tutenges. 2011. "Young tourists visiting strip clubs and paying for sex." Tourism Management 32(4): 869-874. doi:10.1016/j.tourman.2010.08.002.

Hobbs, Jeffrey Dale, Piengpen Na Pattalung, and Robert C. Chandler. 2011. "Advertising Phuket's Nightlife on the Internet: A Case Study of Double Binds and hegemonic masculinity in Sex Tourism." Journal of Social Issues in Southeast Asia 26(1): 80-104. doi: 10.1355/sj26-le.

Huysamen, Monique, and Floretta Boonzaier. 2015. "Men's constructions of masculinity and male sexuality through talk of buying sex." Culture, Health \& Sexuality 17(5): 541-554. doi:10.1080/13691058.2014.963679.

Jewkes, Rachel. K., Kristin Dunkle, Mzikazi Nduna, and Nwabisa Shai. 2010. “Intimate partner violence, relationship power inequity, and incidence of HIV infection in young women in South Africa: a cohort study." Lancet 376(9734): 41-48. doi:10.1016/S01406736(10)60548-X.

Kendall, Lory. 2000. “"Oh No! I'm a Nerd!": Hegemonic masculinity on an Online Forum.” Gender \& Society 14(2): 256-274. doi:10.2307/190274.

Khruakham, Seksan, and Brian Lawton. 2012. "Assessing the Impact of the 1996 Thai Prostitution Law: A Study of Police Arrest Data." Asian Journal of Criminology 7(1): 2336. doi:10.1007/s11417-010-9100-9. 
Kong, Travis S. K. 2015. "Romancing the boundary: client masculinities in the Chinese sex industry." Culture, Health \& Sexuality 17(7): 810-824. doi:10.1080/13691058.2015.1004197.

Lim, Soo Jin, and Shu Xu Cheah. 2016. Risky Pleasures. SAGE Open 6(2). doi:10.1177/2158244016650241

Lyttleton, Chris. 2000. Endangered Relations: Negotiating Sex and AIDS in Thailand. Amsterdam: Harwood Academic Publishers.

Manago, Adriana M. 2013. "Negotiating a sexy masculinity on social networking sites." Feminism \& Psychology 23(4): 478-497. doi:10.1177/0959353513487549.

Manieri, Marco., Hampus Svensson, and Martin Stafström. 2013. "Sex tourist risk behaviour An on-site survey among Swedish men buying sex in Thailand." Scandinavian Journal of Public Health 41(4): 392-397. doi:10.1177/1403494813480572.

Manopaiboon, C., D. Prybylski, W. Subhachaturas, S. Tanpradech, O. Suksripanich, U. Siangphoe, and S. J. Whitehead. 2013. "Unexpectedly high HIV prevalence among female sex workers in Bangkok, Thailand in a respondent-driven sampling survey." International Journal of STD \& AIDS 24(1): 34-8. doi:10.1177/0956462412472300.

Markham, Annette, and Elizabeth Buchanan. 2012. "Ethical Decision-Making and Internet Research: Recommendations from the AoIR Ethics Working Committee (Version 2)". Accessed May 2 2017. http://aoir.org/reports/ethics2.pdf.

Mason, Mark. 2010. "Sample size and saturation in PhD studies using qualitative interviews." Forum Qualitative Sozialforschung / Forum: Qualitative Social Research. Accessed April 7 2016. http://www.qualitative-research.net/index.php/fqs/article/view/1428/3027.

Mizuno, Yuko, David W. Purcell, M. Latka, L. Mary H. Latka, Lisa R. Metsch, Cynthia A. Gomez, and Carl A. Latkin. 2007. "Beliefs that Condoms Reduce Sexual Pleasure - Gender 
Differences in Correlates Among Heterosexual HIV-Positive Injection Drug Users (IDUs).” Journal of Urban Health 84(4): 523-536. doi:10.1007/s11524-007-9162-x.

Nhurod, P., L. J. M. Bollen, P. Smutraprapoot, O. Suksripanich, U. Siangphoe, R. Lolekha, P. Manomaipiboon, C. Nandavisai, R. Anekvorapong, S. Supawitkul, W. Subhachaturas, P. Akarasewi, and K. K. Fox. 2010. "Access to HIV testing for sex workers in Bangkok, Thailand: a high prevalence of HIV among street-based sex workers." The Southeast Asian Journal of Tropical Medicine and Public Health 41(1): 153-62.

Parreñas, Rhacel Salazar. "Trafficked - Filipino Hostesses in Tokyo's Nightlife Industry." Yale Journal of Law and Feminism 18(1): 145-180.

Plummer, David C. 2013. "Masculinity and Risk: How Gender Constructs Drive Sexual Risks in the Caribbean." Sexuality Research and Social Policy 10(3): 165-174. doi:10.1007/s13178-013-011.

Rice, B., V. L. Gilbart, J. Lawrence, R. Smith, M. Kall, and V. Delpech. 2012. "Safe travels? HIV transmission among Britons travelling abroad." HIV Medicine 13(5): 315-317. doi:10.1111/j.1468-1293.2011.00983.

Ridge, Damien Thomas. 2004. “"It was an incredible thrill': the social meanings and dynamics of younger gay men's experiences of barebacking in Melbourne.” Sexualities 7(3): 259-279. doi:10.1177/1363460704040138.

Ryan, C. and M. Hall. 2001. Sex Tourism: Marginal People and Liminalities. New York: Routledge.

Sanders, Teela. 2005. "Sexing "It's just acting”: Sex workers' strategies for capitalizing on sexuality." Gender, Work \& Organization 12(4): 319-342. doi:10.1111/j.14680432.2005.00276.

Sanders, Teela. 2008. "Male sexual scripts: Intimacy, sexuality and pleasure in the purchase of commercial sex." Sociology 42(3): 400-417. doi:10.1177/0038038508088833. 
Singh, J. P., and Shilpa. A. Hart. 2007. "Sex Workers and Cultural Policy: Mapping the Issues and Actors in Thailand." Review of Policy Research 24(2): 155-173. doi:10.1111/j.15411338.2007.00274.x

Swan, Holly, and Daniel J. O'Connell. 2011. "The impact of intimate partner violence on women's condom negotiation efficacy." Journal of Interpersonal Violence 27(4): 775-92. doi:10.1177/0886260511423240.

Syvertsen, Jennifer L., Angela Robertson Bazzi, Gustavo Martinez, M. Gudelia Rangel, Monica D. Ulibarri, Kirkpatrick B. Fergus, Hortensia Amaro, and Steffanie A. Strathdee. 2015. "Love, Trust, and HIV Risk Among Female Sex Workers and Their Intimate Male Partners." American Journal of Public Health 105(8): 1667-1674. doi:10.2105/AJPH.2015.302620

Treerutkuarkul, A. 2010. "Thailand's new condom crusade." Bulletin of the World Health Organization 88(6): 404-405. doi:10.2471/BLT.10.010610.

Treffke, Henry, Marika Tiggemann, and Michael W. Ross. 1992. "The relationship between attitude, assertiveness and condom use." Psychology \& Health 6(1-2): 45-52. doi:10.1080/08870449208402020.

Wariki, Windy. M. V, Erika Ota, Rintaro Mori, Ai Koyanagi, Narumi Hori, and Kenji. Shibuya. 2012. "Behavioral interventions to reduce the transmission of HIV infection among sex workers and their clients in low- and middle-income countries." Cochrane Database of Systematic Reviews CD005272. doi:10.1002/14651858.CD005272.pub3.

Williams, Sophie, Lenore Lyons, and Michele Ford. 2008. "It's about Bang for Your Buck, Bro: Singaporean Men's Online Conversations about Sex in Batam, Indonesia.” Asian Studies Review 32(1): 77-97. doi:10.1080/10357820701870767.

Williams, Erica Lorraine. 2013. Sex tourism in Bahia: ambiguous entanglements. Champaign: University of Illinois Press. 
Wright, Eric R. 2003. “Travel, tourism, and HIV risk among older adults.” Journal of Acquired Immune Deficiency Syndromes 33(Sup: S233-S237. doi:10.1097/00126334-20030601200023.

Yokota, Fumihiko. 2006. "Sex behaviour of male Japanese tourists in Bangkok, Thailand." Culture, Health \& Sexuality 8(2): 115-131. doi:10.1080/13691050500526068. 